A. Winter $\cdot$ B. Rost $\cdot$ H. Hilbrecht $\cdot$ M. Elbrächter

\title{
Vertical and horizontal distribution of coccolithophores in the Caribbean Sea
}

Received: 1 February 2001 / Accepted: 25 July 2002 / Published online: 3 October 2002

(C) Springer-Verlag 2002

\begin{abstract}
Coccolithophores are one of the major, living phytoplankton groups and play important roles in geochemical cycles and climate. They are a particularly dominant group in oligotrophic waters, yet a lot more needs to be learned about their horizontal and vertical distributions. Coccolithophores were collected at different photic depths from 15 stations across the Caribbean Sea during cruise 35/1 of the RV Meteor from April to May 1996. A total of 67 species was identified, with an average of 19 species per station. Coccolithophores were encountered at nearly all stations but abundances were fairly low $\left(10^{2}-10^{3}\right.$ cells $\left.1^{-1}\right)$. Coccolithophore assemblages in the four oceanographical provinces identified (Granada Basin waters, Atlantic surface waters, northern Caribbean waters, and Pedro Bank waters) differed in their species composition and abundances. Abundance peaks occurred near the surface and in the deeper photic zone $(140-150 \mathrm{~m})$ just below the deep chlorophyll-a maximum at the top of the nitrate nutricline.
\end{abstract}

\section{Introduction}

Coccolithophores are one of the major phytoplankton groups in the oceans. There are about 200 species which have been classified so far (Jordan and Green 1994; Cros et al. 2000; Jordan et al. 2000), although newly discovered hetero/holococcolith combinations are continually reducing their number (Cros et al. 2000). The biogeographical zonations and depth habitats of a few of these species have been well documented and show that they prefer to live within certain depth ranges and latitudinal zones (Winter et al. 1994). Emiliania huxleyi and Gephyrocapsa oceanica, two species which are probably closely related (Medlin et al. 1996), are bloom-forming organisms which are thought to modify biogeochemical cycles of, amongst others, $\mathrm{CO}_{2}$ (Tyrrell and Taylor 1995; Winter 1996), climate (DMS-cloud cover; Charlson et al. 1987; Ayers et al. 1991) and light scattering-albedo (Balch et al. 1991; Tyrrell et al. 1999). Most of our understanding of coccolithophores stems from work undertaken in intense coastal upwelling regions and high latitudes where they often occur in great numbers (exceeding $10^{6}$ cells $1^{-1}$, Balch et al. 1991). Much less is known about the role of coccolithophores in oligotrophic nutrient-depleted regions where they are often the dominant taxa, perhaps because of their special adaptation to these environments (extreme k-selection; Young 1994). Successful strategies of coccolithophores may include using coccoliths as buoyancy-control to reach prevailing nutrients (Wilbur and Watabe 1963; Klaveness and Paasche 1979), and reducing diffusion limitation of nutrient uptake by possessing higher sinking rates than other phytoplankton in the same size group (Smayda and Bienfang 1983). In the laboratory E. huxleyi showed the fastest nutrient uptake (=lowest half-saturation constant) for nitrate and ammonium uptake out of 16 species (Eppley et al. 1969). In general, oceanic coccolithophores are able to grow at much lower iron, zinc and manganese concentrations than other coastal phytoplankton (Brand et al. 1983). Most other 
tropical oceanic species remain at low abundances during natural and artificial nutrient enrichment (Hulburt 1983).

Coccolithophore diversity is lowest for strongly eutrophic communities but it is also low in extreme oligotrophic conditions. The highest diversity of coccolithophores is found in oligotrophic waters like subtropical oceanic gyres (Hulburt 1963, 1964). The miscellaneous group ( $>80 \%$ of the species assemblage but $<20 \%$ of the total abundance) shows substantial abundance in intermediate conditions (e.g., Honjo 1976). The oligotrophic regions of the world's oceans are often overlooked but these regions have a deeper mixed layer and a deeper photic zone than eutrophic regions. Consequently, the total phytoplankton biomass production in oligotrophic regions may often be underestimated. The ratio of oligotrophic (low nutrient supply, coccolithophore-carbonate dominated) vs. eutrophic (high nutrient supply, diatom-organic matter dominated) volume of the world's ocean has been implicated as an important mechanism for changes in the partition of $\mathrm{CO}_{2}$ between the ocean and atmosphere (Dymond and Lyle 1985). Therefore, it is important to understand the role of coccolithophores in oligotrophic regions. This paper addresses some of these questions, including the vertical and horizontal distributions of coccolithophores in the Caribbean Sea.

\section{The Caribbean Sea}

The Caribbean Sea (Fig. 1) is well situated for studying the response of coccolithophores to different oceanographic features under tropical oligotrophic conditions. During Meteor cruise M35/1 we encountered four oceanographical settings which we designate northern Caribbean waters (stations $\mathrm{A}$ to $\mathrm{C}$ - which combine stations $\mathrm{C} 1$ and $\mathrm{C} 2$; gradient circles), Pedro Bank waters (stations D to G; open circles), Atlantic surface waters (stations $\mathrm{H}$ to $\mathrm{L}$; closed circles), and Granada Basin waters (filter stations $\mathrm{M}$ to $\mathrm{O}$; shaded circles).

Hydrographic conditions (temperature, salinity, density and chlorophyll-a) during the cruise are presented in Fig. 2. The latitudinal excursions of the intertropical convergence zone (ITCZ) and associated precipitation in the Amazon Basin produce two major climatic and hydrographic seasons in the Caribbean. During summer and fall, runoff from the Orinoco and Amazon Rivers approaches the Caribbean Sea and leads to the formation of low-salinity lenses at the surface (e.g., Wüst 1964; Gordon 1967; Müller-Karger et al. 1988, 1989; Corredor and Morell 2001). These surface waters have increased nutrient and phytoplankton pigment concentrations (Froehlich et al. 1978; MüllerKarger et al. 1989; Bidigare et al. 1993; Corredor and Morell 2001).

Meteor cruise 35/1 approached the Caribbean in the winter/spring season when the trade winds prevail and the low-salinity lenses are restricted to the southeastern and southern parts of the Caribbean. This area is characterized by a relatively steep seasonal thermocline, raised isotherms, and a strong deep chlorophyll maximum associated with the seasonal thermocline. We refer to this area as the Granada Basin waters (stations $\mathrm{M}-\mathrm{O}$; Fig. 1).

The northeastern Caribbean and the Anegada Passage (Fig. 1) are characterized by a smooth "subtropi-
Fig. 1 Map showing locations of sampling stations $(A-O)$ in the Caribbean Sea. Stations $A-C$ Northern Caribbean waters, $D-G$ Pedro Bank waters, $H-L$ Atlantic surface waters, $M-O$ Granada waters

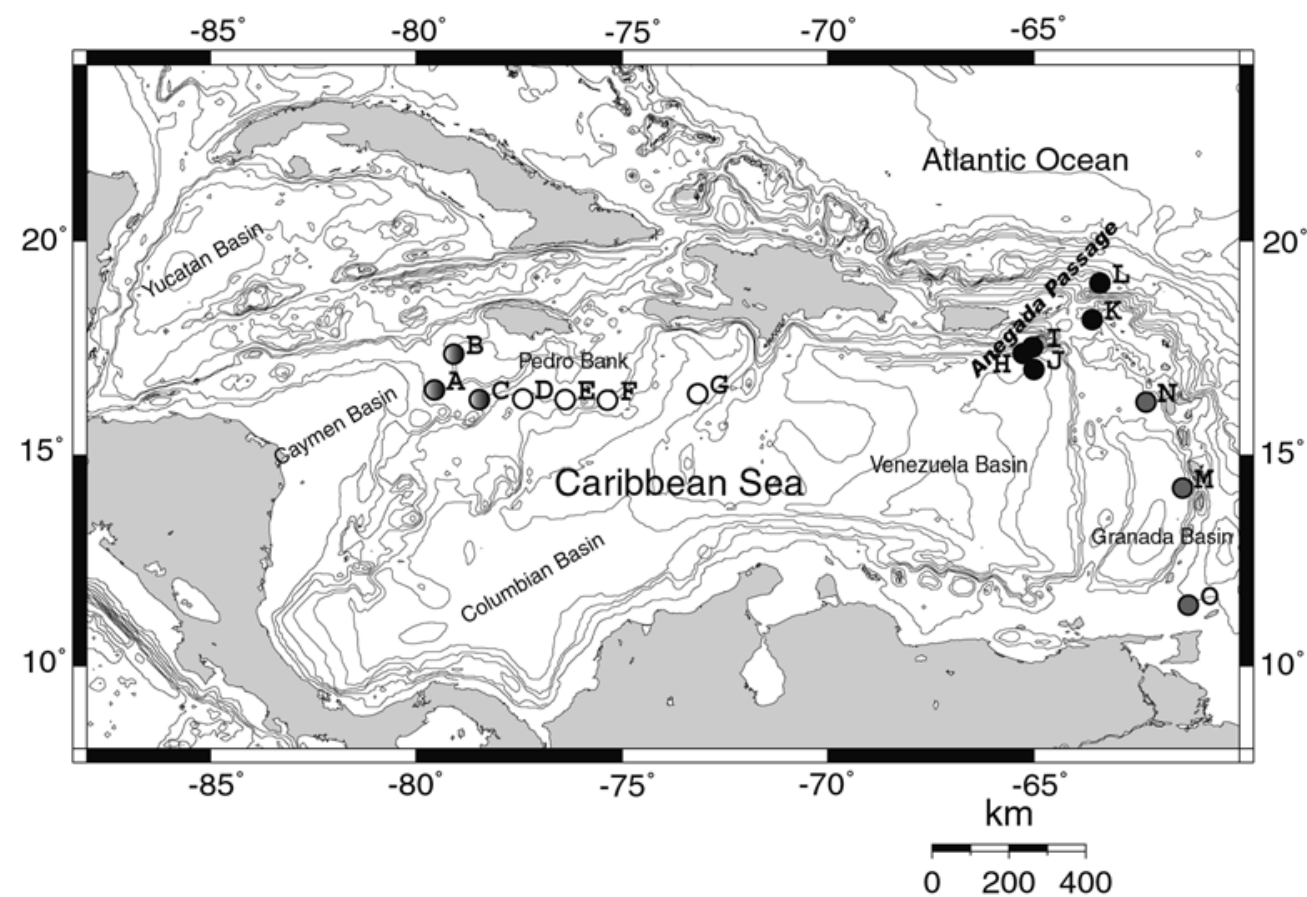



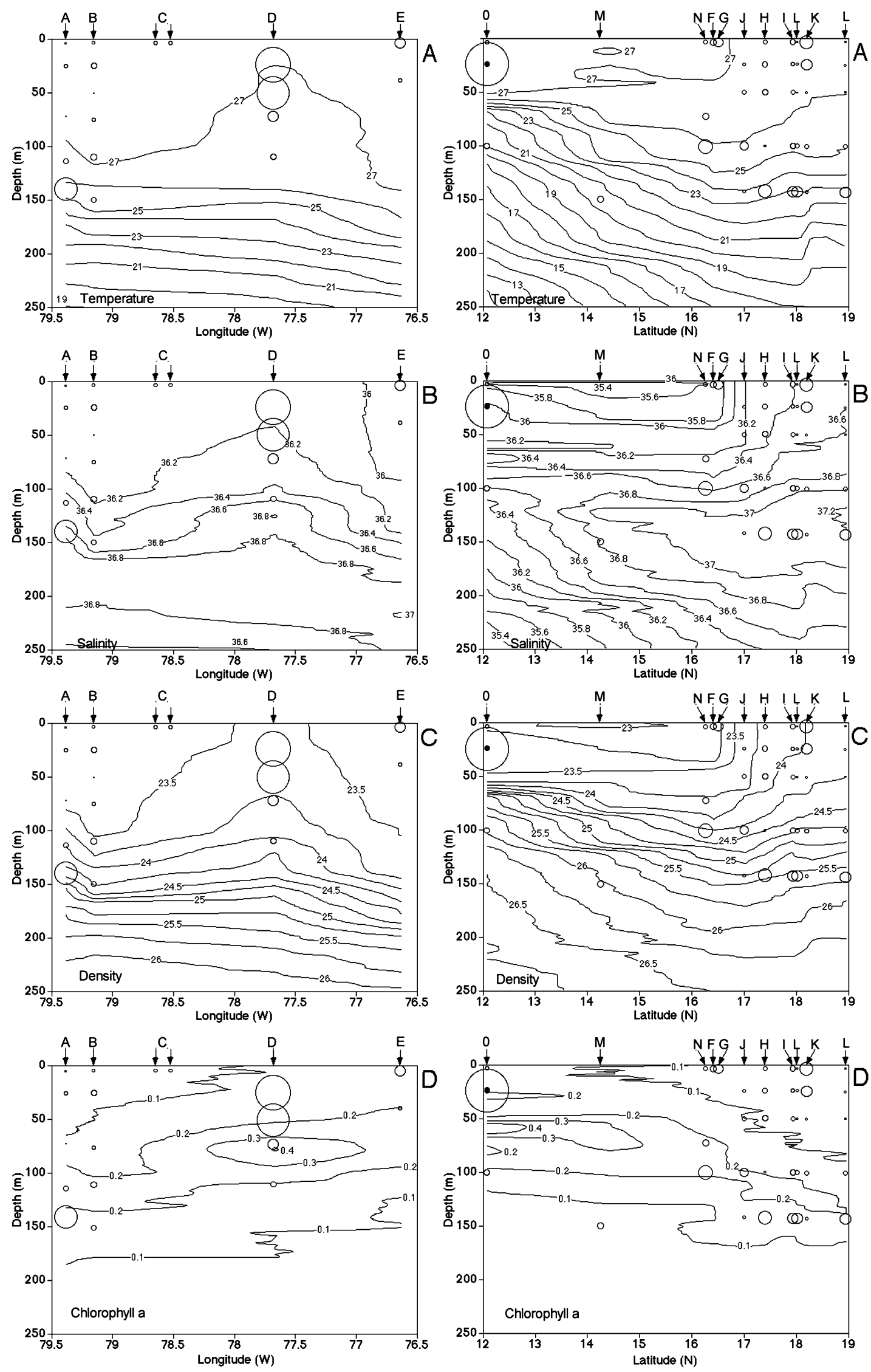

western transect

nannoplankton standing stocks: \begin{tabular}{lll}
\hline & & 20000 \\
0 & & \\
& &
\end{tabular} 
Fig. 2A-D Coccolithophore abundances (circles) and physical/ biological parameters (contours) encountered during RV Meteor cruise 35/1 in the eastern Caribbean (Barbados-Anegada PassagePuerto Rico). Circles indicate the depths at which nannoplankton samples were obtained with a rosette water sampler, and the size of the circles represent coccolithophore abundances (cells $1^{-1}$ ). Panels are divided into western section (left panels shown by longitude; stations $A-E$ ) and eastern section (right panels shown by latitude; stations $H-O)$. A Temperature $\left({ }^{\circ} \mathrm{C}\right.$ ), B salinity (psu), C density $\left(\mathrm{kg} \mathrm{m}^{-3}\right)$, D chlorophyll-a $\left(\mu \mathrm{g} \mathrm{l}^{-1}\right)$ derived from fluorescence. For location of stations, see map in Fig. 1

cal" seasonal thermocline and oligotrophic conditions with a deep and broad chlorophyll maximum (Fig. 2, right panels). The lower salinity of the surface waters relative to most parts of the tropical Atlantic derives, in part, from the dilution by Amazon River water (Moore and Todd 1993). This water, however, has a long residence time and is depleted in nutrients. We refer to this oligotrophic area as the Atlantic surface waters (stations $\mathrm{H}-\mathrm{L}$ ).

Northern Caribbean waters (Fig. 2, left panels; Fig. 1, stations A-C) experience deep mixing induced by the trade winds primarily in winter and spring. This produces a deep mixed layer and a gradual change in water density with depth below the mixed layer. The strong differences in mixed layer depths between the northeastern Atlantic waters and the northern Caribbean waters can be assigned to the fetch of the trade winds which blow in a NE-SW direction. The chlorophyll concentrations suggest oligotrophic conditions in the northern Caribbean waters.

Pedro Bank waters (stations $D-G$ ) derive from interaction with this shallow carbonate platform, resulting in localized upwelling and increased plankton biomass. The upwelling water derives from a depth of between 100 and $150 \mathrm{~m}$, which coincides with the mixed layer depth in this area during RV Meteor cruise $35 / 1$.

\section{Materials and methods}

The samples were retrieved from 15 different stations (A-O; stations $\mathrm{C} 1$ and $\mathrm{C} 2$ combined) during cruise 35/1 of the RV Meteor between 18 April and 15 May 1996 (Barbados-Ponce; Fig. 1, Table 1). Temperature, salinity, and fluorescence depth profiles were measured with a portable CTD at plankton sampling sites to determine water structure and chlorophyll-a concentrations. A rosette water sampler equipped with 10-1 Niskin bottles was deployed to collect ocean water. Usually five bottles were taken from $3,25,50,100$, and $140 \mathrm{~m}$ (Table 1). The lowermost samples were taken at or near the fluorescence peak (Fig. 2D). At three of the stations (C, F, G), only surface samples were obtainable with the ship's independent water-pump system which consists of a continuous-flow seawater intake system and is kept very clean for scientific use only. In all, 48 water samples were filtered. On average, 61 (4-7 1) was filtered through 0.8-um, 47-mm-diameter cellulose Millipore filters at low vacuum (5 psi) and washed thoroughly with de-ionized water ( $\mathrm{pH}$ 7). Afterwards, the filters were airdried. Coccolithophore abundances (Table 1, upper lines) were counted by examining a $16-\mathrm{mm}^{2}$ area on the filter (equivalent to a minimum of $10-\mathrm{ml}$ water throughput) with cross nicols of a polarizing microscope at $1,250 \times$ magnification. Isolated coccoliths were neglected. For five of the 48 samples, the number of liters filtered was not recorded and abundance counts were impossible (Table 1, marked with $\mathrm{x}$ ). For species identification a rectangular portion $\left(0.5 \mathrm{~cm}^{2}\right)$ of the filter was coated with gold-palladium and placed on a stub for viewing with a Zeiss digital scanning electron microscope 850 (Gothenburg University) and Zeiss 950 (BAH-List).

\section{Results}

Abundance

Coccolithophore abundances for the 48 filters (Table 1) examined by polarizing microscope ranged between $10^{1}$ and $10^{4}$ cells $1^{-1}$. The mean abundance for all filter

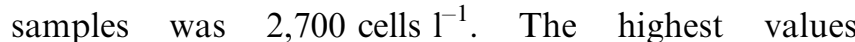
$\left(10^{4}\right.$ cells $\left.1^{-1}\right)$ occurred at two stations, D (Pedro Bank 25 and $50 \mathrm{~m}$ ) and $\mathrm{O}$ (Granada Basin $25 \mathrm{~m}$; Table 1).

We combined samples into three depth zones: the upper photic zone $(3-25 \mathrm{~m})$, middle photic zone $(40-110 \mathrm{~m})$, and deep photic zone $(140-150 \mathrm{~m})$, based on results of this cruise and previous work by Okada and Honjo (1973), Winter et al. (1994), and Jordan and Chamberlain (1997). The upper photic zone had a mean abundance of 3,875 cells $1^{-1}$, the middle photic zone of 1,668 cells $1^{-1}$, and the deep photic zone of 2,171 cells $1^{-1}$. With the exception of stations $\mathrm{D}$ and $\mathrm{O}$, there was no significant difference between abundances of the three photic zones because the standard deviations generally overlapped (data not shown). Also, there was no marked difference in coccolithophore abundances between the western and eastern parts of the transect. Half of the stations $(n=7)$ with samples collected from 140-150 m water depths showed abundance peaks at these deepest sampling depths.

\section{Diversity}

Sixty-seven species were identified from a total of 3,035 specimens examined from the 48 filters observed by SEM (Appendix). The average number of species in the water column per station was 19 . The highest number of species (42) was recorded at station $\mathrm{D}$, followed by stations K (31), N (26) and I (21). The highest number of species at any given water depth (Table 1) occurred at station D (32 at $50 \mathrm{~m}$, and 23 at $25 \mathrm{~m}$ ). There was no 
difference in species diversity between the western and eastern parts.

\section{Distribution}

The vertical and horizontal percent distribution of coccolithophores sorted according to the 25 most abundant species is presented in Fig. 3. Eight species
Fig. 3 Relative abundances of coccolithophore species (above 2\%) in the four oceanographic provinces encountered during Meteor cruise $35 / 1$ at deep, intermediate and shallow depths. Note the dominance of E. huxleyi in shallow waters, except in the Atlantic waters where $U$. irregularis is the most abundant species. Variation in the dominance of E. huxleyi and species of Umbellosphaera at intermediate depths are also characteristic for the oceanographic provinces. In deep surface waters the abundance of Florisphaera is expected, accept for abundant E. huxleyi in northern Caribbean waters

Table 1 Coccolithophore water sampling locations as well as species/specimen count information taken during Caribbean cruise M35/1

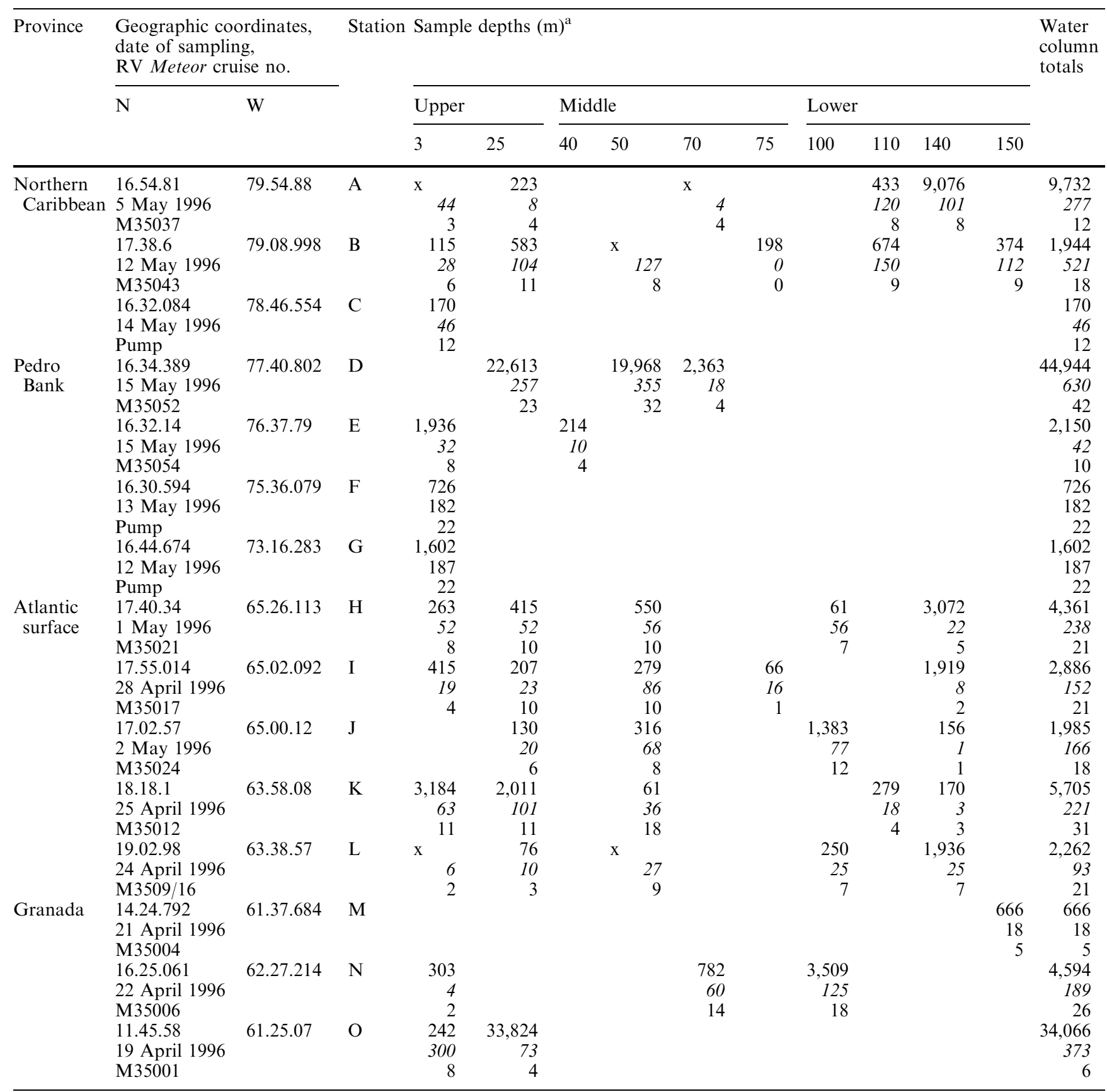

${ }^{\text {a }}$ Sample depths: first line, abundances (cells ${ }^{-1}$ ); second line (italics), specimens counted; third line, species; $\mathrm{x}$, no abundance counts possible; station B $(75 \mathrm{~m})$, no cells were identified by SEM but abundance counts were possible by light microscope 

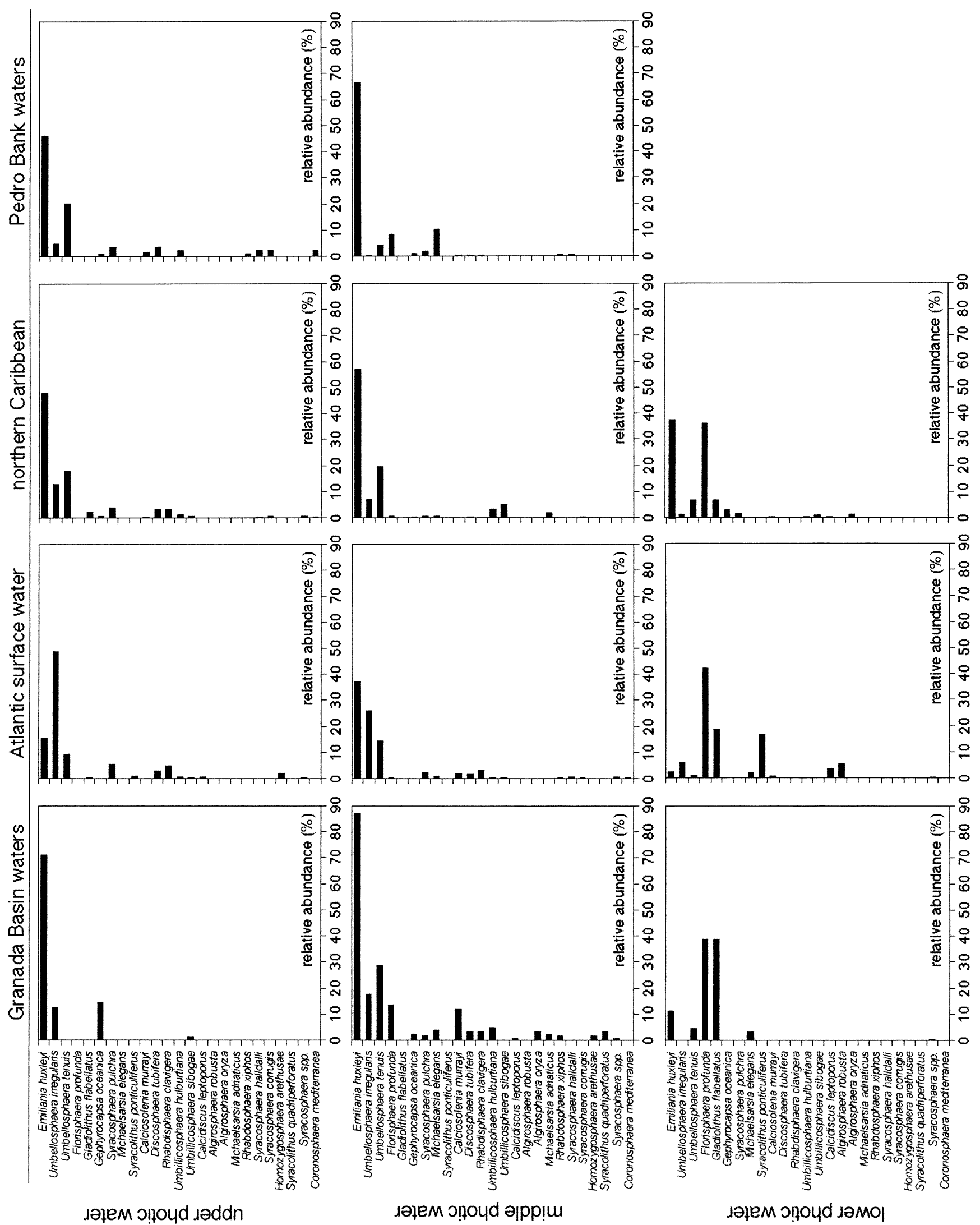
comprised about $82 \%$ of all those identified in the Caribbean, these being (in order of importance) E. huxleyi, Umbellosphaera irregularis, Umbellosphaera tenuis, Florisphaera profunda, Gladiolithus flabellatus, Rhabdosphaera clivigera, Syracosphaera pulchra, and Gephyrocapsa oceanica. The most dominant species by far on all the filters observed was E. huxleyi $($ mean $=43 \%)($ Fig. 3$)$.

Because the common approach (cf. below) of counting 300 specimens per station was not possible given the low abundances, our strategy was to combine stations according to the four surface water masses (Granada Basin, Atlantic surface, northern Caribbean surface, and Pedro Bank waters). Here we describe the salient features of the resulting distribution patterns. E. huxleyi was found at all depths in this study. It was the most abundant species at nearly all stations, except for the Atlantic surface waters in the lower photic zone. At this location $F$. profunda and Gladiolithus flabelatta dominated. Highest species richness occurred in the Pedro Bank samples at upper and middle depths. $U$. tenuis and $U$. irregularis were evenly distributed in the upper and middle photic zones at all stations, except for the upper photic zones of the Granada Basin waters where $U$. tenuis was nearly absent (Fig. 3) and replaced by G. oceanica. Of interest is the presence of Calciosolenia murrayi in middle photic waters throughout the study area, except in those of the northern Caribbean waters, and also various occurrences of Syracolithus ponticuliferus in the deeper photic zone of the Atlantic surface waters (cf. not among the top 25 but in the top 30 species).

\section{Discussion}

The results of the present study show that average coccolithophore abundance $\left(10^{3}\right.$ cells $\left.1^{-1}\right)$ was fairly low and ranged from 0 to $10^{4}$ cells $1^{-1}$. These values are representative of coccolithophore abundance in nutrient-poor gyres and oligotrophic seas (Winter et al. 1994). Earlier investigations in the Caribbean Sea (Throndsen 1972; Jordan and Winter 2000) revealed very similar abundance ranges. At some sites in this study coccolithophores were very rare to absent. Other workers have also reported the near-complete absence of coccolithophores in similar settings, for example, the Central North Pacific Gyre and Bermuda (Cortés 1997; Haidar et al. 2000). In fact, productivity has been difficult to measure in subtropical waters because of the highly fluctuating production and dispersion of phytoplankton in oligotrophic waters (Taguchi et al. 1988).

The number of species identified (67; Appendix) is higher than that found by Throndsen (1972) during May in the Caribbean (48 species) but not as high as the 104 taxa identified from January to May 1995 by Jordan and Winter (2000) and Jordan et al. (2000) who counted 25,000 specimens. The number of species identified per sample in the present study seems clearly to be a near-linear function $\left(r^{2}=0.73\right)$ of the total number of specimens per filter counted (Fig. 4a). As is well known, however, the linear function would eventually become asymptotic had enough specimens been counted (Preston 1962), assuming that each station is part of the same community. Counting 300 specimens per sample has become common practice and seems to be the optimal number for a statistically significant representation of the assemblage (Pielou 1966). Counting less than 300 specimens can underestimate species diversity. Nevertheless, when coccolithophore abundances are low, as in the Caribbean Sea, counting 300 specimens on a filter can be very time consuming and may not add substantially to information on diversity. Figure $4 \mathrm{~b}$ shows that the filter area needed to count 300 specimens is primarily a logarithmic function of specimen abundance in the water column. At abundance levels encountered in this study

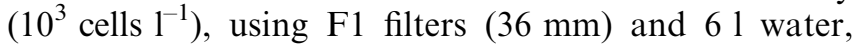
one would need to scan an area of approximately $60 \mathrm{~mm}^{2}$ to count 300 specimens. Decreasing filter size or increasing the water volume filtered can reduce the filter area required to count 300 specimens by an order of magnitude. Unfortunately, this was not possible for this study because the filters on board were standardized and ocean water was in keen demand by other investigators. In most cases not more than 100 coccolithophore specimens were identified. Using the diversity measurement (Simberloff 1972), it is possible to determine the sample size for any degree of accuracy in estimating species presence. Nevertheless, by counting less than the recommended 300 specimens, the relative percent abundance of the dominant species (usually of most interest) will not change significantly (Kennett 1982).

In this study, we encountered four oceanic provinces (i.e., Granada Basin waters, Atlantic waters, northern Caribbean waters, and Pedro Bank waters) with differing nutrient and physical parameters. Overall, the distributions of the commonly observed species, E. huxleyi, U. irregularis, $U$. tenuis, and $F$. profunda, are influenced by the four water masses. The difference in the coccolithophore assemblages between the western (Pedro Bank and northern Caribbean surface waters) and eastern (Atlantic and Granada surface waters) parts of the Caribbean transect is due mainly to the abundance of E. huxleyi and Umbellosphaera spp. In general, E. huxleyi dominated the western stations whereas Umbellosphaera spp. were more abundant in the east. This is most likely a result of the higher nutrient levels in the western part and the more open ocean conditions. Because oceanic species like $U$. irregularis do not increase in number during nutrient enrichment (Hulburt 1983), the difference in horizontal distribution seems to be mainly a function of E. huxleyi. Under slightly more eutrophic conditions, E. huxleyi outcompetes strongly oligotrophic 
Fig. 4 a Graph showing the relationship between the number of specimens counted and the number of species identified (see text for further discussion). b Filter area needed to count 300 specimens vs. specimen abundance for four different scenarios: circles 51 water filtered through an F1 filter $(12 \mathrm{~mm})$; squares 101 water filtered through an F1 filter $(12 \mathrm{~mm})$, triangles 51 water filtered through an F2 filter $(36 \mathrm{~mm})$, crosses 101 water filtered though an F2 filter (36 mm)
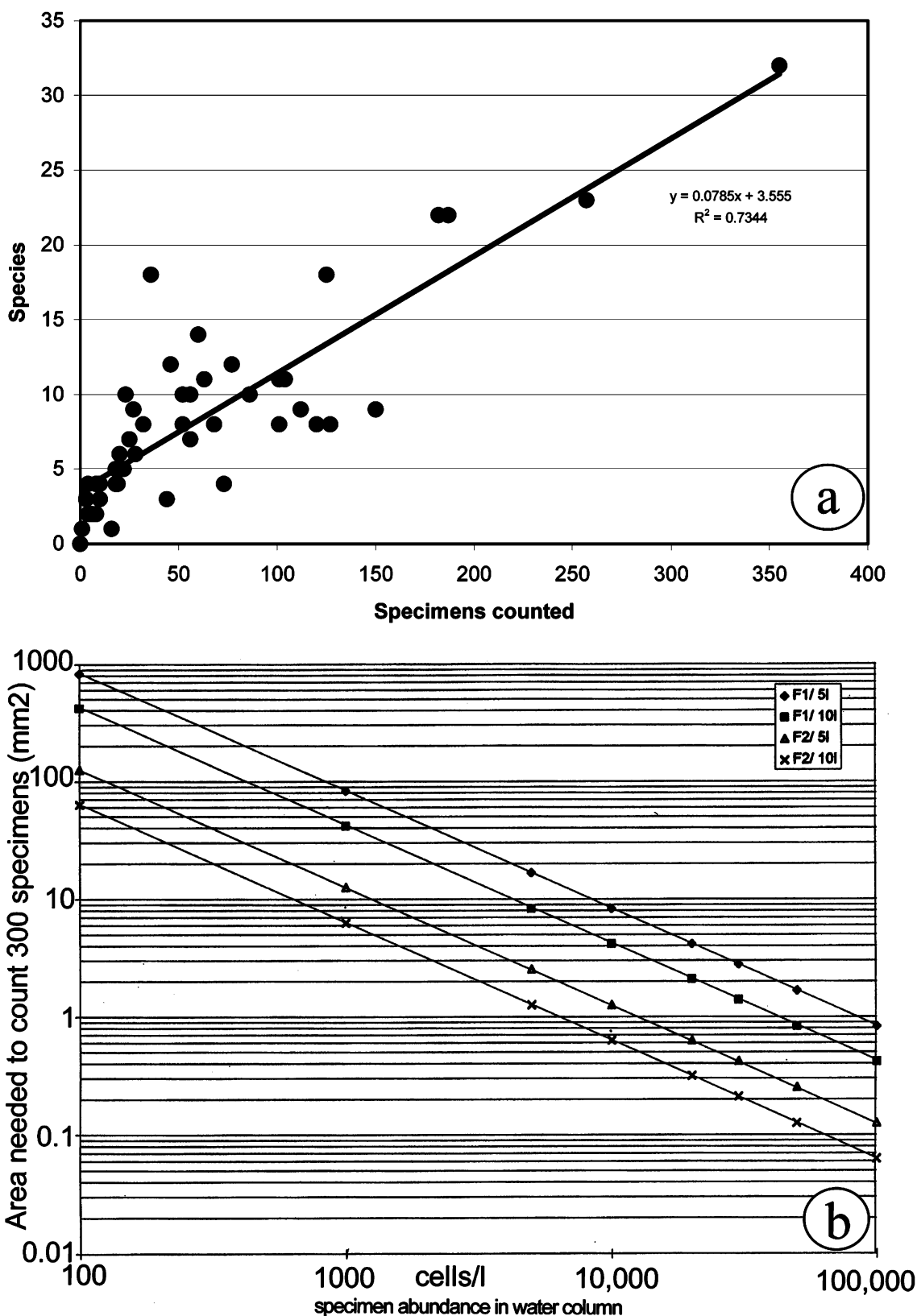

umbelliform coccolithophores. In the deeper photic zone, the floriform coccolithophores made up only $40 \%$ in the west but clearly predominated $(>80 \%)$ in the east.

The order of magnitude higher coccolithophore abundances, especially at $25-\mathrm{m}$ water depth (station O) in the Granada waters, were probably due to the influences of increased nutrient supply. These sites in the Granada Basin are under the influence of Orinoco and Amazon river runoff which is enriched in nutrients (Froehlich et al. 1978). The high number of $G$. oceanica $(>25 \%)$ in the Granada upper photic waters is also evidence of the high nutrient conditions in the Granada Basin. G. oceanica has been reported as an upwelling species (see Winter et al. 1994, p. 40 for references) which blooms at a lower salinity than $E$. huxleyi (Kleijne et al. 1989). In the neritic Gulf of Panama it was also found to be the dominant species (Smayda 1966; Throndsen 1972). In the oligotrophic Caribbean, it has been only rarely observed (Throndsen 1972).

The northern Caribbean surface water assemblages are typical for oligotrophic waters (Okada and Honjo 1975). The close vicinity of the Pedro Bank may be the reason for the high coccolithophore abundances observed in Pedro Bank waters. The shallow Pedro Bank (water depth approx. $20 \mathrm{~m}$ ) is a source of productivity through upwelling in the upper $120 \mathrm{~m}$ of the water column. This is reflected by relatively high chlorophylla concentrations at this site (Fig. 2). Compared with 
other upwelling regions, however, the coccolithophore abundances at this location are not very high (Winter et al. 1994).

The deep photic zone is populated mainly by floriform coccolithophores which live within or below the thermocline under low light and temperature conditions. High abundances of coccolithophores were found directly below the deep chlorophyll maximum (DCM), consisting mainly of $F$. profunda and $G$. flabellatus. It is usually not recognized that substantial biomass production occurs in deeper waters, especially in models which rely on satellite image analysis. In eutrophic waters light attenuation is low mostly due to the high abundance of plankton and aggregates in the shallow mixed layer. The autotrophic community in eutrophic waters is limited to the mixed layer, unlike oligotrophic communities where photosynthetically available radiation is available for photosynthesis at greater depths.

These floriform coccolithophores are unique in that they are adapted to the high nitrate and low light levels (Cortés 1997) associated with the deeper photic zone below the DCM. This also means they do not have to compete with the DCM flora. Their coccoliths seem to be especially arranged to take advantage of the high refractive index of calcite by forming an inverted bowl which refracts light into the cell (Gartner and Bukry 1969), and their coccospheres are particularly large relative to the cell size. In addition, floriform coccolithophores probably are motile (Young 1994), which may allow them to move vertically in the water in search of optimal depth light/nutrient conditions. It is interesting in this regard to note that in a study of primary productivity in the Caribbean, Taguchi et al. (1988) found that most ${ }^{14} \mathrm{C}$ uptake occurred at the chlorophyll maximum and at night time, which may be a result of heterotrophy at these depths.

Exclusive surface monitoring of phytoplankton will result in underestimation of coccolithophore abundances in the photic zone. Although light is obviously a limiting factor for coccolithophores within the water column, the absolute lower limit where coccolithophores live in the water column is unknown and needs to be investigated further. In warm oligotrophic waters the nutrient-level is usually the limiting factor for plankton (Brand 1994). In tropical sediments Florisphaera specimens are often difficult to detect but constitute the greatest percentage of coccoliths (e.g., Okada 1983; Molfino and McIntyre 1990; Tanaka 1991).

The vertical distribution of coccolithophores in the Caribbean in this study seems to be typical for tropical-subtropical regions (Okada and Honjo 1973). In the upper and middle photic zones placolith-bearing and umbelliform coccolithophores dominate. Usually E. huxleyi is the most important species, followed by $U$. irregularis and $U$. tenuis. E. huxleyi seems to thrive at high light levels (Nanninga and
Tyrrell 1996) because it has a lack of photoinhibition at intensive light levels (up to at least 1,000 ${\text { in } \mathrm{m}^{-2}}^{-2}$ $\mathrm{s}^{-1}$ ). Furthermore, there is an enhanced level of photoadaption (Lewis et al. 1984), and E. huxleyi also has an exceptionally high $\mathrm{P}$ uptake rate (Riegman et al. 2000). Umbellosphaera spp. are well adapted to oligotrophic, nutrient-depleted waters and are usually found in subtropical latitudes $\left(10-30^{\circ} \mathrm{N}\right)$ between 0 - and 100-m depths (Okada and Honjo 1973). Their absence in high-latitude, oligotrophic waters implies that they tolerate neither low temperatures nor low light levels (Young 1994, p. 75). This may be the reason for their minor role in the deep photic assemblage. Our results concur with the coccolithophore ecology and functional morphology strategy developed by Brand (1994), Young (1994), and Winter et al. (1994). This approach suggests that coccolithophore distribution is basically controlled by water masses, and species-specific $\mathrm{r}-\mathrm{K}$ strategies whereby $\mathrm{K}$-selected species, such as Umbellosphaera, easily adapt to stable but difficult environments whereas r-selected species, such as E. huxleyi, can rapidly exploit resources. In the deep photic zone the floriform coccolithophores dominate because of the special adaptations mentioned above.

Up to now there are about 200 species of heterocococcolithophore and holococcolithophore species described (Jordan and Green 1994; Jordan et al. 2000). There is increasing evidence, however, that at least some holococcolithophore taxa are life-cycle stages perhaps the haploid stage - of heterococcolithophore taxa (Cros et al. 2000). This will reduce the number of valid taxa. Consistent with the findings of Young (1994), we observed high abundances $(20 \%$ of the assemblage) of the holococcolithophore $S$. ponticuliferus in the deep surface waters of the Atlantic, together with floriform species. Perhaps this species is a life-cycle stage of a common heterococcolithophore? Cros et al. (2000) showed (1) that Syracolithus catilliferus is a lifecycle stage of Helicosphaera carteri, and (2) that $S$. catilliferus and Syracolithus confusus are variants of the same species. The very similar "species" Syracolithus dalmaticus and Syracolithus schilleri are very probably also produced by Helicosphaera. Conversely, Syracolithus quadriperforatus, Syracolithus bicorium and Syracolithus sp. B (Kleijne) are all very different (twolayered wall structure with totally different crystallographic orientation). As $S$. ponticuliferus shows the same structure as $S$. catilliferus, it is reasonable to assume that it is formed either by a Helicosphaera sp. or (if somewhat different) maybe by Pontosphaeral Scyphosphaera.

\section{Conclusions}

The coccolithophore abundance in the Caribbean is low and varies in the range $0-10^{4}$ cells $1^{-1}$. In all, 67 species were identified of which four are dominant: $E$. 
huxleyi, $U$. irregularis, $U$. tenuis, and $F$. profunda. These species are typical for oligotrophic waters. Significant information on the relative percent abundance of dominant species can be obtained by counting less than 300 specimens per sample. This reduces the need to scan large filter areas for samples taken in oligotrophic areas with low standing stocks of coccolithophores. The coccolithophore assemblages in the four oceanographic provinces differ in their species composition and abundance, and the dominant species. There is a relatively high abundance of coccolithophores in the lower photic zone, and total absence of coccolithophores at some locations. This pattern needs to be considered in models of ocean carbon budgets and ground-truthing of satellite-derived data. $F$. profunda occurs just below the deep chlorophyll-a maximum at the top of the nitrate nutricline.

Acknowledgements We thank the crew of the RV Meteor, Carlos Garcia and Juliana Fenner for assisting in sampling. The University of Puerto Rico provided release time to participate in the cruise, and travel funds to A.W. to work on the SEM. Thanks go to Joe Scheer for helping to construct the filtration apparatus. H.H. received support from the ETH Zürich and the Swiss National Science Foundation. We thank H. Halliger, List/Sylt for technical assistance.

\section{Appendix}

Species list according to Jordan and Kleijne (1994)

except where references are given

Acanthoica quattrospina Lohmann

Algirosphaera oryza Schlauder

Algirosphaera robusta (Lohmann) Norris

Alisphaera unicornis Okada and McIntyre

Anacanthoica acanthos (Schiller) Deflandre

Anacanthoica cidaris (Schlauder) Kleijne

Calcidiscus leptoporus (Murray \& Blackman) Loeblich

and Tappan

Calciopappus caudatus Gaarder and Ramsfjell

Calciosolenia murrayi Gran

Calyptrolithina multipora (Gaarder) Norris

Calyptrosphaera oblonga Lohmann

Ceratolithus cristatus Kamptner

Corisphaera sp. type A (in Kleijne 1961)

Corisphaera gracilis Kamptner

Corisphaera tyrrheniensis Kleijne

Coronosphaera binodata (Kamptner) Gaarder

Coronosphaera mediterranea (Lohmann) Gaarder

Daktylethra pirus (Kamptner) Norris

Discosphaera tubifera (Murray \& Blackman) Ostenfeld

Emiliania huxleyi (Lohmann) Hay \& Mohler

Florisphaera profunda Okada \& Honjo var. profunda

Flosculosphaera calceolariopsis Jordan \& Kleijne

Gephyrocapsa muellerae Bréhéret

Gephyrocapsa oceanica Kamptner
Gladiolithus flabellatus (Halldal \& Markali) Jordan and Chamberlain (1993)

Gliscolithus amitakareniae Norris

Hayaster perplexus (Bramlette \& Riedel) Bukry

Helicosphaera pavimentum Okada \& McIntyre

Helicosphaera carteri (Wallich) Kamptner var. carteri

Helladosphaera cornifera (Schiller) Kamptner

Homozygosphaera triarcha Halldal \& Markali

Homozygosphaera arethusae (Kamptner) Kleijne

Michaelsarsia adriaticus (Schiller) Manton et al.

Michaelsarsia elegans Gran emend. Manton et al.

Neosphaera coccolithomorpha Lecal-Schlauder

Ophiaster hydroideus (Lohmann) Lohmann emend.

Manton \& Oates

Ophiaster reductus Manton \& Oates

Periphyllophora mirabilis (Schiller) Kamptner

Poricalyptra isselii (Borsetti \& Cati) Kleijne

Poritectolithus maximus Kleijne

Poritectolithus poritectus (Heimdal) Kleijne

Rhabdosphaera clavigera Murray \& Blackman var. clavigera

Rhabdosphaera xiphos (Deflandre \& Fert) Norris

Syracolithus catilliferus (Kamptner) Deflandre

Syracolithus ponticuliferus (Kamptner) Kleijne \& Jordan

Syracolithus quadriperforatus (Kamptner) Gaarder

Syracolithus schilleri (Kamptner) Loeblich and Tappan

Syracosphaera anthos (Lohmann) Jordan and Young

Syracosphaera corolla Lecal

Syracosphaera corrugis Okada \& McIntyre

Syracosphaera epigrosa Okada \& McIntyre

Syracosphaera exigua Okada \& McIntyre

Syracosphaera halldalii Gaarder

Syracosphaera lamina Lecal-Schlauder

Syracosphaera molischii Schiller

Syracosphaera nodosa Kamptner

Syracosphaera orbiculus Okada \& McIntyre

Syracosphaera ossa (Lecal) Loeblich and Tappan

Syracosphaera pirus Halldal and Markali

Syracosphaera prolongata Gran ex Lohmann

Syracosphaera pulchra Lohmann

Syracosphaera rotula Okada \& McIntyre

Umbellosphaera irregularis Paasche

Umbellosphaera tenuis (Kamptner) Paasche

Umbilicosphaera hulburtiana Gaarder

Umbilicosphaera sibogae var. foliosa (Kamptner) Okada \& McIntyre

Zygosphaera hellenica Kamptner

\section{References}

Ayers GP, Ivey JP, Gillett RW (1991) Coherence between seasonal cycles of dimethyl sulfide, methanesulphonate and sulphate in marine air. Nature 349:404-406

Balch WM, Holligan PM, Ackleson SG, Voss KJ (1991) Biological and optical properties of mesoscale coccolithophore blooms in the Gulf of Maine. Limnol Oceanogr 36:629-643 
Bidigare RA, Ondrusek ME, Brooks JM (1993) Influence of the Orinoco River outflow on distributions of algal pigments in the Caribbean Sea. J Geophys Res 98:2259-2269

Brand LE (1994) Physiological ecology of marine coccolithophores. In: Winter A, Siesser WG (eds) Coccolithophores. Cambridge University Press, Cambridge, pp 39-49

Brand LE, Sunda WG, Guillard RRL (1983) Limitation of marine phytoplankton reproductive rates by zinc, manganese, and iron. Limnol Oceanogr 28:1182-1198

Charlson RJ, Lovelock JE, Andreae MO, Warren SG (1987) Oceanic phytoplankton, atmospheric sulphur, cloud albedo and climate. Nature 326:655-661

Corredor JE, Morell JM (2001) Seasonal variation of physical and biogeochemical features in eastern Caribbean surface waters. J Geophys Res 106(C3):4517-4525

Cortés M (1997) Living coccolithophore distribution from the Central North Pacific Gyre: vertical, seasonal and interannual variations. PhD Thesis, Swiss Institute of Technology, Zurich

Cros L, Billard C, Kleijne A, Zeltner A, Young JR (2000) New examples of holococcolith-heterococcolith combination coccospheres and their implications for coccolithophorid phylogeny. Mar Micropaleontol 39:1-34

Dymond J, Lyle M (1985) Flux comparisons between sediments and sediment traps in the eastern tropical Pacific; implications for atmospheric $\mathrm{CO}_{2}$ variations during the Pleistocene. Limnol Oceanogr 30:699-712

Eppley RW, Rogers JN, McCarthy JJ (1969) Half-saturation constants for uptake of nitrate and ammonium by marine phytoplankton. Limnol Oceanogr 14:912-920

Froehlich PN Jr, Atwood DK, Giese GS (1978) Influence of Amazon River discharge on surface salinity and dissolved silicate concentrations in the Caribbean Sea. Deep-Sea Res 25:735-744

Gartner S, Bukry D (1969) Tertiary holococcoliths. J Paleontol 43:1213-1221

Gordon AL (1967) Circulation in the Caribbean Sea. J Geophys Res 72:6207-6223

Haidar AT, Thierstein HR, Deuser WG (2000) Calcareous phytoplankton standing stocks, fluxes and accumulation in Holocene sediments off Bermuda (N. Atlantic). Deep-Sea Res, part I, Topical Studies in Oceanography 47:1907-1938

Honjo S (1976) Coccoliths: production, transportation, and sedimentation. Mar Micropaleontol 1:65-79

Hulburt EM (1963) The diversity of phytoplanktonic populations in oceanic, coastal, and estuarine regions. J Mar Res 21:81-93

Hulburt EM (1964) Succession and diversity in the plankton flora of the western North Atlantic. Bull Mar Sci Gulf Carib 14:3344

Hulburt EM (1983) Quasi K-selected species, equivalence, and the oceanic coccolithophorid plankton. Bull Mar Sci 33:197-212

Jordan RW, Chamberlain AHL (1993) Canistrolithus valliformis gen et sp nov (Syracosphaeraceae, Prymnesiophyta), a comparison with the genus Alisphaera. Phycologia 32(5):373

Jordan RW, Chamberlain AHL (1997) Biodiversity among haptophyte algae. Biodiv Conserv 6:131-152

Jordan RW, Green JC (1994). A check-list of the extant Haptophyta of the world. J. Mar Biol Assoc UK 74:149-174

Jordan RW, Kleijne A (1994) A classification system for living coccolithophores. In: Winter A, Siesser WG (eds) Coccolithophores. Cambridge University Press, Cambridge, pp 83105

Jordan RW, Winter A (2000) Assemblages of coccolithophorids and other living microplankton off the coast of Puerto Rico during January-May 1995. Mar Micropaleontol 39:113-130

Jordan RW, Broerse ATC, Hagino K, Kinkel H, Sprengel C, Takahashi K, Young JR (2000) Taxon lists for studies of modern nannoplankton. Mar Micropaleont 39:309-314

Kennett JP (1982) Marine geology. Prentice-Hall, Englewood Cliffs

Klaveness D, Paasche E (1979) Physiology of coccolithophorids. In: Levandowsky M, Hutner SH (eds) Biochemistry and physiology of Protozoa, vol 1. Academic Press, New York, pp $191-213$
Kleijne A (1961) Holococcolithophorids from the Indian Ocean, Red Sea, Mediterranean Sea and North Atlantic Ocean. Mar Micropaleontol 17(1-2):1-76

Kleijne A, Kroon D, Zevenboom W (1989) Phytoplankton and foraminiferal frequencies in northern Indian Ocean and Red Sea surface waters. Neth J Sea Res 24:531-539

Lewis MR, Cullen JJ, Platt F (1984) Relationships between vertical mixing and photo-adaptation of phytoplankton: similarity criteria. Mar Ecol Prog Ser 15:141-149

Medlin LK, Barker GLA, Campbell L, Green JC, Hayes PK, Marie D, Wrieden S, Vaulot D (1996) Genetic characterisation of Emiliania huxleyi (Haptophyta). J Mar Syst 9:13-31

Molfino B, McIntyre A (1990) Precessional forcing of nutricline dynamics in the Equatorial Atlantic. Science 249:766-769

Moore WS, Todd JF (1993) Radium isotopes in the Orinoco estuary and the eastern Caribbean Sea. J Geophys Res 98:22332244

Müller-Karger FE, McClain CR, Richardson PL (1988) The dispersal of the Amazon's water. Nature 333:56-59

Müller-Karger FE, McClain CR, Fisher TR, Esaias WE, Varela R (1989) Pigment distribution in the Caribbean Sea: Observations from space. Progr Oceanogr 23:23-64

Nanninga JH, Tyrrell T (1996) Importance of light for the formation of algal blooms by Emiliania huxleyi. Mar Ecol Prog Ser 136:195-203

Okada H (1983) Modern nannofossil assemblages in sediments of coastal and marginal seas along the western Pacific Ocean. Utrecht Micropaleontol Bull 30:171-187

Okada H, Honjo S (1973) The distribution of oceanic coccolithophorids in the Pacific. Deep-Sea Res 20:355-374

Okada H, Honjo S (1975) Distribution of coccolithophores in the marginal seas along the western Pacific Ocean and in the Red Sea. Mar Biol 31:271-285

Pielou EC (1966) The measurement of diversity in different types of biological collections. J Theor Biol 13:131-144

Preston FW (1962) The canonical distribution of commonness and rarity, part I. Ecology 43:185-215.

Riegman R, Stolte W, Noordeloos AAM, Slezak D (2000) Nutrient uptake, and alkaline phosphate (EC 3:1:3:1) activity of Emiliania huxleyi (Prymnesiophyceae) during growth under $\mathrm{N}$ and $\mathrm{P}$ limitation in continuous cultures. J Phycol 36:87-96

Simberloff D (1972) Models in biogeography. Freeman Cooper, San Francisco

Smayda TJ (1966) A quantitative analysis of the phytoplankton of the Gulf of Panama. III. General ecological conditions, and the phytoplankton dynamics at $8^{\circ} 45^{\prime} \mathrm{N}, 79^{\circ} 23^{\prime} \mathrm{W}$ from November 1954 to May 1957. Bull Inter-Am Trop Tuna Comm 11:355612

Smayda TJ, Bienfang PK (1983) Suspension properties of various phyletic groups of phytoplankton and tintinnids in an oligotrophic, subtropical system. Mar Ecol 4:289-300

Taguchi S, DiTullio GR, Laws EA (1988) Physiological characteristics and production of mixed layer and chlorophyll maximum phytoplankton populations in the Caribbean Sea and western Atlantic Ocean. Deep-Sea Res 35:1363-1377

Tanaka Y (1991) Calcareous nannoplankton thanatocoenoses in surface sediments from seas around Japan. Sci Rep Tohoku Univ 2nd ser 61:127-198

Throndsen J (1972) Coccolithophorids from the Caribbean Sea. Norw J Bot 19:51-60

Tyrrell T, Taylor AH (1995) Latitudinal and seasonal variations in carbon dioxide and oxygen in the northeast Atlantic and the effects on Emiliania huxleyi and other phytoplankton. Global Biogeochem Cycles 9:585-604

Tyrrell T, Holligan PM, Mobley CD (1999) Optical impacts of oceanic coccolithophore blooms. J Geophys Res 104:3223-3241

Wilbur KM, Watabe N (1963) Experimental studies on calcification in molluscs and the alga Coccolithus huxleyi. Ann NY Acad Sci 109:82-112

Winter A (1996) The role of coccolithophores in the global carbon cycle. Carib J Sci 32:302 
Winter A, Jordan RW, Roth PH (1994) Biogeography of living coccolithophores in ocean waters. In: Winter A, Siesser WG (eds) Coccolithophores. Cambridge University Press, Cambridge, pp 161-177

Wüst G (1964) Stratification and circulation of the AntilleanCaribbean Basins. Part I. Spreading and mixing of water types with an oceanographic atlas. Columbia University Press, New York

Young JR (1994) Functions of coccoliths. In: Winter A, Siesser WG (eds) Coccolithophores. Cambridge University Press, Cambridge, pp 63-82 